Article

\title{
Development of Downy Birch (Betula pubescens Ehrh.) Coppice Stands during Nine Years
}

\author{
Jyrki Hytönen
}

Natural Resources Institute Finland, Natural Resources, Teknologiakatu 7, FI-67100 Kokkola, Finland; Jyrki.hytonen@luke.fi; Tel.: +35-82-9532-3405

Received: 6 August 2020; Accepted: 31 August 2020; Published: 1 September 2020

\begin{abstract}
Growing of dense, naturally regenerated downy birch stands using rotations of 24-26 years has been shown to be profitable. Coppicing would be a low-cost regeneration method, however, knowledge on the development of birch coppices is scarce. The height, stem number, and biomass development of sprouts originating from six clearcut stands in three age classes (A: 10-12 years, B: 15-16 years, C: 22-24 years) located in northern Finland was studied. Equations for estimating the aboveground biomass from height were developed for sprouts. The number of sprouts, and their height and biomass were measured annually during nine growing seasons. In addition, sprout damage was assessed. The number of sprouts per hectare was highest in the youngest age class (A) throughout the study period, even though the decrease in the number of stems due to self-thinning was also fastest (from 591,000 sprouts per ha to 105,000 sprouts per ha). The stand age class did not have an effect on either the mean $(2.7 \mathrm{~m})$ or dominant height $(5.4 \mathrm{~m})$ of birch sprouts. The total leafless above-ground biomass, the mean annual increment (MAI), and the current annual increment (CAI) were highest in the youngest stand age class (A) and lowest in the oldest age class (C). After 9 years, the biomass in the oldest age class was $15.1 \mathrm{Mg} \mathrm{ha}^{-1}$ and $31.1 \mathrm{Mg} \mathrm{ha}^{-1}$ in the youngest age class. During the first six years, the biomass of the sprouts correlated with the number of stumps. A higher number of stumps produced more sprouts and biomass in the first years. However, due to faster self-thinning in the densest stands and higher mass of average sprout in the oldest stands, the correlation between the number of stumps and biomass decreased with the increase of age so that it was no longer significant in years 7, 8, and 9. In the older stand age classes, the MAI increased with the increase of the age of sprouts. The CAI varied considerably between the study years. The study showed that due to coppice vigor, growth of the birch sprouts can be high.
\end{abstract}

Keywords: coppicing; sprouts; biomass; height; stand density; downy birch

\section{Introduction}

Fast-growing tree plantations subject to more intensive practices and shorter rotation periods than conventional forestry are expected to yield high amounts of biomass for energy and other end uses. Mostly, the growing of species in the genera of Populus and Salix has been studied and, for example, the area of practical willow plantations in Sweden is almost 10,000 ha [1]. The potential productivity of willow plantations decreases from south to north [2], and simultaneously the risk for frost damage increases [3]. Thus a local species adapted to the climate could be an alternative option. Downy birch (Betula pubescens Ehrh.) growing on peatland areas could be a feasible option in northern Finland. According to the Finnish National Forest Inventory, $98 \%$ of the total birch volume consists of downy birch on peatlands in Northern Finland [4]. Downy birch is a biologically vigorous, early successional, pioneer tree species thriving on peatlands and in mineral soils with poor drainage. Downy birch is used mainly for pulpwood and energy wood. 
The current peat production area in Finland is about 68,000 hectares. The need to reduce greenhouse gas emissions and environmental concerns are increasing the need to reduce the use of peat as fuel. Thus considerable amounts of peatlands will be released from production in Finland, and therefore large areas of cutaway peatlands will need a new form of land use in the coming years. Many studies have shown that dense downy birch stands can be cost-efficiently established on cutaway peatlands by natural regeneration or by sowing following ash fertilization $[5,6]$. Ash fertilization, or soil preparation on shallow peat layers is required due to the low potassium and phosphorus reserves of the bottom peat.

Energy wood production by growing dense downy birch stands with rotations of over 20 years has been calculated to be economically feasible on cutaway peatlands [7]. These calculations were based on the assumption that the future stand can be achieved by coppicing and that coppicing shortens the rotation by one year. However, results on the development of coppiced birch stands to verify this assumption are lacking. Re-sprouting after harvest and maintaining productivity is fundamental to short-rotation coppice forestry, which utilizes the exceptional growth rates of stump sprouts or root suckers [8]. The initiation structure and sprouting characteristics of downy birch dormant basal buds are well known [9-11]. Young sprouts are able to grow much faster than seedlings of the same age, mainly due to the root system of parent trees. However, it is not fully clear how long the growth advantage of downy birch coppice seedlings is maintained over seed-originated trees [12]. Those factors (e.g., season of cutting, stump height, age, and size of the trees) influencing the sprouting of downy birch are well known [13-18].

In this study, the development of six birch coppice stands was monitored annually for nine years. The main hypothesis was that stand dynamics and biomass production depend on the age and diameter of the clearcut birch trees.

\section{Materials and Methods}

Two naturally regenerated dense unthinned downy birch stands with some willow undergrowth from each of the three age classes (A: 10-12 years; B: 15-16 years; C: 22-24 years) were selected from the same cutaway peatland area located in northern Finland at Liminka (Hirvineva, $64^{\circ} 48^{\prime} \mathrm{N}, 25^{\circ} 24^{\prime} \mathrm{E}$ ). The depth of the residual peat layer varied from 18 to $60 \mathrm{~cm}$. The estimates of the stand ages were based on the mean biological age of dominant trees on each sampled stand. Their ages were determined from increment cores taken from the base and by adding two years to the number of annual rings. The age variation within the dominant trees was small, mostly 2-3 years, indicating that the stands were even-aged and had been established in a short period of time. The mean age of the dominant trees in the six stands varied from 10 to 24 years, and their mean height from 2.8 to $9.0 \mathrm{~m}$ (Table 1). Each of the stands was clear-cut manually except for the two oldest stands which were cut by a harvester in the spring (6 May 2011). After cutting, the trees were removed from the study plots (size 520-1800 $\mathrm{m}^{2}$ ) established in the stands.

Circular sub-sample plots (1-4 in each stand, size 30-150 $\mathrm{m}^{2}$ depending on the density of the stands) were established on each of the study plots. Since the aim was to measure a similar number of stumps from each stand, larger-sized sub-sample plots were established in the center of the clearcut older stands. In the younger and denser stands, 3-4 smaller sub-sample plots distributed uniformly over the clearcut areas were established. One study plot was destroyed after the eighth year. The missing values for this plot were calculated using regression imputation [19], in which the existing data from years one to eight were used to make the prediction. The degree of the determination of the regression equations was high (e.g., biomass, 99.5\%; biomass of average sprout, $99.4 \%$; mean height, $99.5 \%$; dominant height, $99.6 \%$ ). During nine years of study, the height of all sprout-originated birches and willows and naturally regenerated birches were measured at the end fo the growing season from ground level to the top of the sprouts. In addition, the sprout damage was assessed. The mean height of the origin of the sprouts [20] was deducted from the measured height of the sprouts. The dominant height of sprouts was calculated as the mean height of $10 \%$ of the tallest sprouts. The total number of sprouts measured in the first growing season was 6874. 
Altogether, 90 birch and 86 willow sample sprouts covering the height variations were taken for modeling the biomass production. Each year, new taller sample sprouts were taken and new equations were calculated. The leafless sprouts were transported to the laboratory and their dry-mass was determined after drying at $105^{\circ} \mathrm{C}$ to constant weight. The biomass of the sprouts was estimated with an allometric model based on the sample tree data

$$
Y=a^{*} X^{b}
$$

In the model, $\mathrm{Y}=\operatorname{dry}$-mass $(\mathrm{g})$, and $\mathrm{X}=$ height of sprouts $(\mathrm{cm})$, while $\mathrm{a}$ and $\mathrm{b}=$ constants. The models were corrected after logarithmic transformation linearizing the allometric equation with $\mathrm{s}^{2} / \mathrm{s}$. The $R^{2}$ values for the birch equations were $89.2 \%-95.3 \%$ and $93.7 \%-96.7 \%$ for the willow (Table 2 ). The coefficient of variation was lower for willows than for birch. The biomass of the birch and willow sprouts growing in the plots was calculated each year with the models based on sprout height.

Table 1. Stand age, stand density, mean height and leafless above-ground biomass of the stands before clearcutting, and the number of measured stumps, their mean diameter, number of measured downy birch sprouts, and share of non-sprouting birch stumps after the first growing season after clearcutting and number of sub-sample plots.

\begin{tabular}{|c|c|c|c|c|c|c|c|c|c|}
\hline Age & Age Class & $\begin{array}{c}\text { No. Stems } \\
\text { ha }^{-1}\end{array}$ & $\begin{array}{c}\text { Mean } \\
\text { Height, } m\end{array}$ & $\begin{array}{l}\text { Mean Stump } \\
\text { Diameter } \\
\text { (Standard } \\
\text { Deviation), cm }\end{array}$ & $\begin{array}{l}\text { Biomass, } \\
\text { Mg ha }^{-1}\end{array}$ & $\begin{array}{c}\text { No. } \\
\text { Measured } \\
\text { Stumps }\end{array}$ & $\begin{array}{c}\text { No. } \\
\text { Measured } \\
\text { Sprouts }\end{array}$ & $\begin{array}{c}\text { Share of } \\
\text { Non-Sprouting } \\
\text { Stumps, \% }\end{array}$ & $\begin{array}{c}\text { No. } \\
\text { Sub-Sample } \\
\text { Plots (Size, } \\
\text { m }^{2} \text { ) }\end{array}$ \\
\hline 10 & A & 129,100 & 2.8 & $1.0(1.0)$ & 26.8 & 262 & 978 & 6,7 & $4(30)$ \\
\hline 12 & A & 57,800 & 3.6 & $2.4(1.6)$ & 29.3 & 183 & 1255 & 11,4 & $3(40)$ \\
\hline 15 & B & 30,200 & 5.2 & $2.7(1.6)$ & 55.9 & 193 & 1229 & 15,0 & $1(50)$ \\
\hline 16 & B & 45,400 & 4.8 & $2.6(2.3)$ & 33.6 & 423 & 2058 & 13,8 & $2(100)$ \\
\hline 22 & $\mathrm{C}$ & 10,600 & 9.0 & $5.5(3.5)$ & 66.9 & 92 & 688 & 29,3 & $3(150)$ \\
\hline 24 & C & 12,200 & 9.0 & $8.2(4.2)$ & 76.2 & 105 & 666 & 29,3 & $1(100)$ \\
\hline
\end{tabular}

Table 2. Dry-mass equations for one- to nine-year-old birch and willow sprouts. Equations have the form $Y=a X^{b}$, which after logarithmic transformation have been corrected with $\mathrm{s}^{2} / \mathrm{s} . \mathrm{Y}=$ dry-mass $(\mathrm{g})$, $\mathrm{X}=$ height of sprouts, a and $\mathrm{b}=$ constants, $R^{2}=$ degree of determination, $\mathrm{V}=$ coefficient of variation, and $\mathrm{N}=$ number of sample sprouts, $\mathrm{SEE}=$ standard error of estimate.

\begin{tabular}{ccccccccccccc}
\hline Age & $\mathbf{N}$ & $\mathbf{a}$ & $\mathbf{b}$ & $\boldsymbol{R}^{\mathbf{2}}, \mathbf{\%}$ & $\mathbf{V}, \mathbf{\%}$ & $\mathbf{S E E}$ & $\mathbf{N}$ & $\mathbf{a}$ & $\mathbf{b}$ & $\boldsymbol{R}^{\mathbf{2}, \boldsymbol{\%}}$ & $\mathbf{V}, \boldsymbol{\%}$ & SEE \\
\hline \multicolumn{9}{c}{ Birch } \\
\hline 1 & 30 & 0.0001432 & 2.496 & 89.2 & 54.9 & 0.5133 & 28 & 0.0002614 & 2.211 & 93.7 & 28.6 & 0.2806 \\
2 & 35 & 0.0001567 & 2.468 & 91.8 & 50.8 & 0.4793 & 35 & 0.0001245 & 2.399 & 94.9 & 33.7 & 0.3278 \\
3 & 45 & 0.0001569 & 2.46 & 93 & 47.1 & 0.4474 & 46 & 0.0000567 & 2.588 & 95.6 & 36.5 & 0.354 \\
4 & 55 & 0.0000723 & 2.638 & 95.1 & 47.4 & 0.45 & 51 & 0.000039 & 2.675 & 95.9 & 38.2 & 0.3692 \\
5 & 75 & 0.0000579 & 2.686 & 94.2 & 53.4 & 0.5006 & 71 & 0.0000296 & 2.754 & 95.3 & 41.1 & 0.3955 \\
6 & 78 & 0.0000478 & 2.729 & 94.5 & 53.9 & 0.505 & 74 & 0.000026 & 2.734 & 95.6 & 40.9 & 0.3937 \\
7 & 83 & 0.0000405 & 2.766 & 94.9 & 53.7 & 0.5035 & 79 & 0.0000217 & 2.814 & 96.3 & 40.2 & 0.3868 \\
8 & 88 & 0.0000315 & 2.821 & 95.1 & 54.6 & 0.5111 & 84 & 0.0000202 & 2.838 & 96.5 & 39.7 & 0.3828 \\
9 & 90 & 0.0000297 & 2.833 & 95.3 & 54.3 & 0.5087 & 86 & 0.0000191 & 2.85 & 96.7 & 39.4 & 0.3800 \\
\hline
\end{tabular}

The average (1990-2019, 30 year period) temperature sum $\left(\mathrm{dd},+5^{\circ} \mathrm{C}\right.$ as the threshold) was $1149 \mathrm{dd}$ and the average June to August precipitation was $193 \mathrm{~mm}$ (Figure 1). Five of the study years were warmer than average, and the average temperature sum of the nine study years (1214 dd) was higher than the 30 year average. Seven of the nine study summers had a higher precipitation than the average figure and the average precipitation for the study years $(222 \mathrm{~mm})$ was higher than the 30 year average. The average precipitation (as snowfall) for January-March was, on average, $85 \mathrm{~mm}$. Exceptionally high precipitation was recorded in winter 2015 (138 mm). 

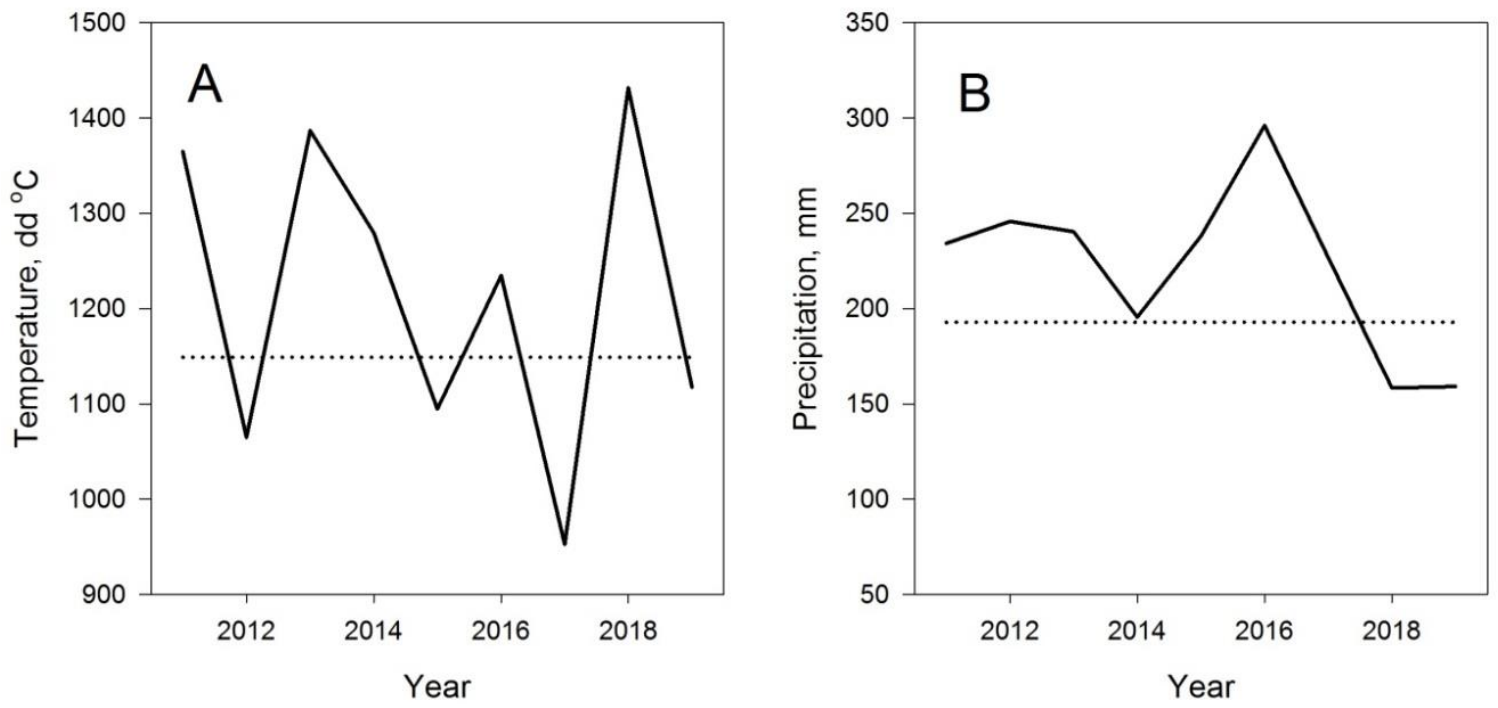

Figure 1. Annual temperature sum (A), (dd threshold value $\left.5{ }^{\circ} \mathrm{C}\right)$ and precipitation $(\mathbf{B})$ in June to August 2011-2019. Dotted lines show a 30-year average.

Repeated measures analysis of variance was used to test the effect of stand age class and time on the studied variables. The homogeneity of variances was tested with Levene's test. When testing figures in percentage form, variance stabilizing transformation of square root arcsine was used. To compare the means of the results, a significance level of $p \leq 0.05$ was used. All statistical analyses were carried out using IBM SPSS Statistics 25 software.

\section{Results}

\subsection{Number of Sprouts}

The number of sprouts per hectare was highest one growing season after clearcutting in all stands (Figure 2A). The stem number was highest in the youngest age class (A) throughout the study period, even though also the decrease of the number of stems due to self-thinning was also fastest (from 591,000 sprouts per ha in year 1 to 105,000 sprouts in year 9). Both the stand age class $(p=0.011)$ and age of spouts $(p<0.001)$ significantly affected the number of sprouts per ha. The significant $(p<0.001)$ age class and sprout age interaction indicated that the number of sprouts per ha in the different age classes approached each other. The share of willows has the highest and that of birches the lowest $(59 \%-61 \%)$ in the youngest age class. The number of willows decreased slightly with the increase of the age of stands. In the oldest age class, $95 \%-99 \%$ of the sprouts consisted of birch (Figure 2B).

Two to three years after clearcutting, naturally regenerated birch seedlings also started to appear in the stands (Figure 3). Their number was highest $4-5$ years after clearcutting, but subsequently, their number decreased. The time following clearcutting had a significant effect $(p<0.002)$ on the number of naturally regenerated seedlings. However, the number of naturally regenerated birch seedlings in the three age classes (age 9-A, 2600; B, 4800; C, 7300 seedlings per ha) did not differ significantly from each other.

\subsection{Height of Sprouts}

The mean height of sprouts increased from $0.6 \mathrm{~m}$ after the first growing season to $2.7 \mathrm{~m}$ after the ninth growing season (Figure 4). Willows in the stands had a similar mean height after the first growing season than birches, but they were $0.6 \mathrm{~m}$ shorter than birches after nine years. The stand age class did not affect the mean height of sprouts. The dominant height of sprouts increased faster with age than the mean height (Figure 4). The dominant height after nine growing seasons ( $5.4 \mathrm{~m}$ ) was two 
times higher than the mean height. The age class did not have a significant effect on the mean height $(p=0.993)$ or the dominant height $(p=0.698)$.
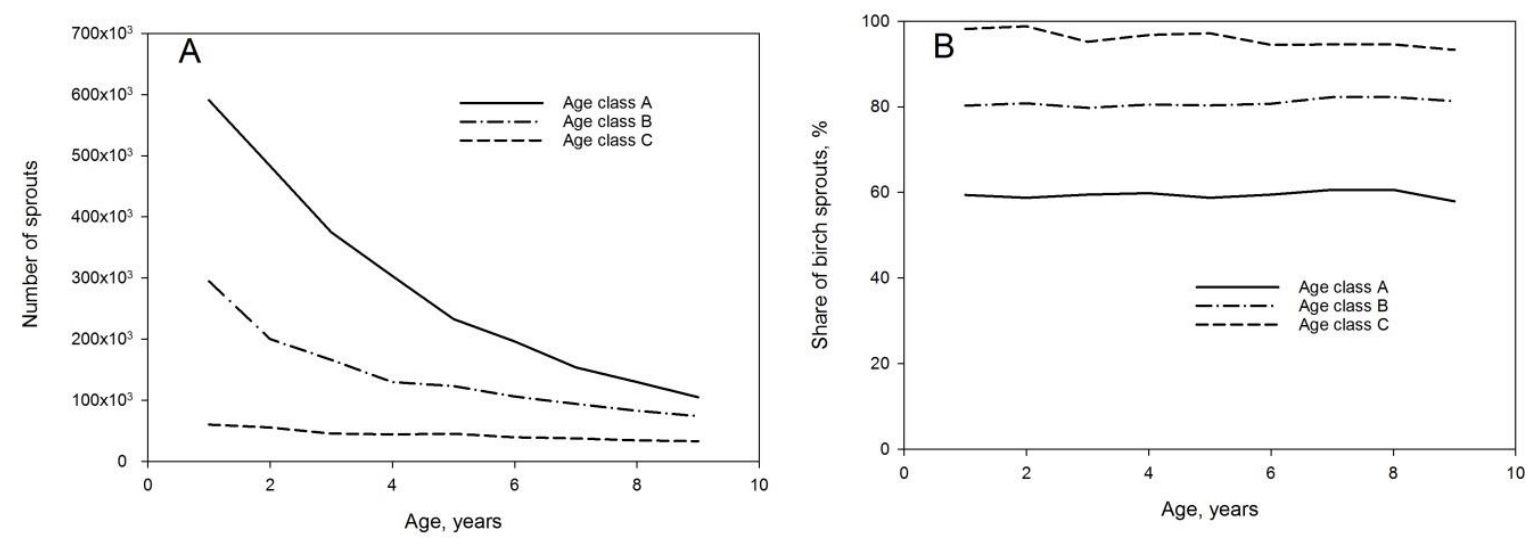

Figure 2. The number of sprouts (A) and share of birch sprouts of the total number of sprouts (B).

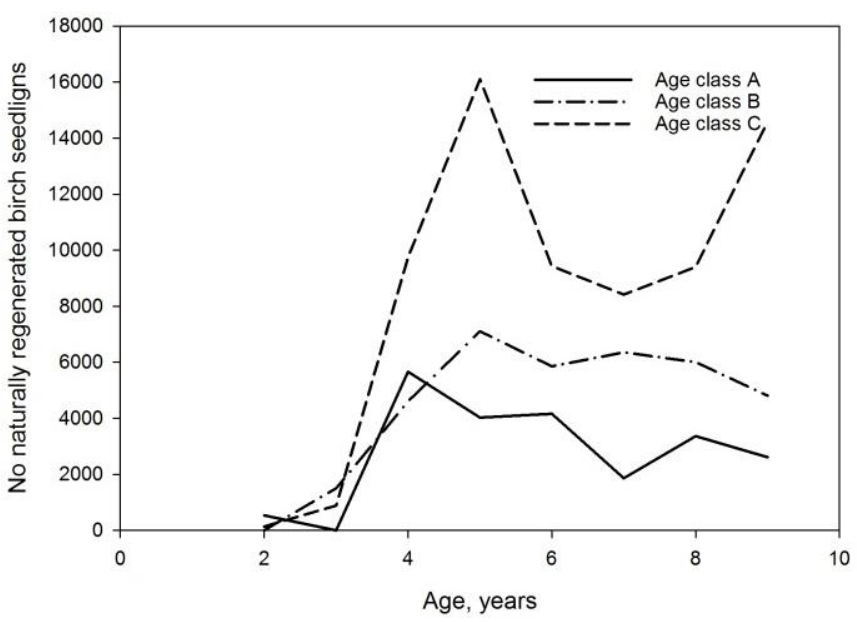

Figure 3. The number of naturally regenerated birch seedlings.

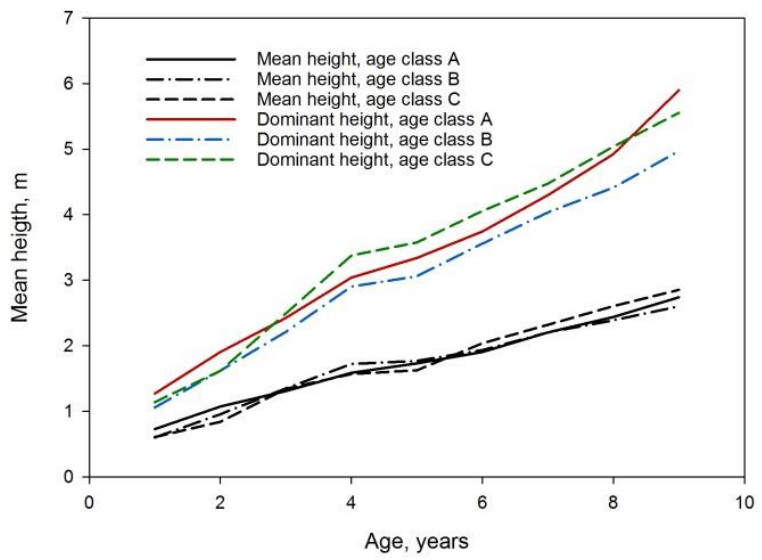

Figure 4. Mean height and dominant height of birch sprouts.

\subsection{Biomass}

The total leafless above-ground biomass was highest in the youngest age class and lowest in the oldest age class (Figure 5A). The effect of age class was significant $(p=0.038)$. After the first growing season, the biomass in the oldest age class was $0.3 \mathrm{Mg} \mathrm{ha}^{-1}$ and it was 18 times higher $\left(3.5 \mathrm{Mg} \mathrm{ha}^{-1}\right)$ in 
the youngest. After 9 years, the biomass in the oldest age class (C) was $15.1 \mathrm{Mg} \mathrm{ha}^{-1}$ and two times higher (31.1 Mg ha ${ }^{-1}$ ) in the youngest (A). The share of birches out of the total biomass was highest in the oldest stand age class (99\%-100\%) and lowest $(73 \%-82 \%)$ in the youngest age class (Figure 5B). The rest of the biomass was almost exclusively willows. The average mass of a sprout increased with the increase of age (Figure 5C). However, the age classes did not differ significantly from each other. During the first six years, the biomass of the sprouts was related to the number of stumps (Table 1). A higher number of stumps produced more sprouts and biomass in the first years. However, due to faster self-thinning in the densest stands and a higher mass of average sprout in the oldest stands, the correlation between the number of stumps and biomass decreased with the increase of age so that it was no longer significant in years 7,8 , and 9 .

The age class had a significant effect $(p=0.030)$ on the mean annual increment (MAI). The MAI was highest in the youngest age class being similar after one and nine growing seasons $\left(3.5 \mathrm{Mg} \mathrm{ha}^{-1}\right.$; Figure 5D). In the older age classes, the MAI increased with the increase of the age of sprouts, reaching $2.5 \mathrm{Mg} \mathrm{ha}^{-1}$ in the second age class (B), and $1.7 \mathrm{Mg} \mathrm{ha}^{-1}$ in the oldest age class (C). The current annual increment (CAI) varied considerably between the study years. The effect of age class on the CAI was not significant $(p=0.201)$, but the effect of year was $(p=0.011)$. The CAI increased annually up to the fourth growing season, reaching $6.2 \mathrm{Mg} \mathrm{ha}^{-1}$ in the youngest age class. However, in the following year, the CAI decreased sharply in all the age classes, especially in the youngest age class, due to snow-damage during the winter following the fourth growing season. Recovery from the damage started in the following summer, but in the youngest age class, the CAI exceeded the MAI only three years after the damage. In the older age classes, the CAI exceeded the MAI already in the following summer.
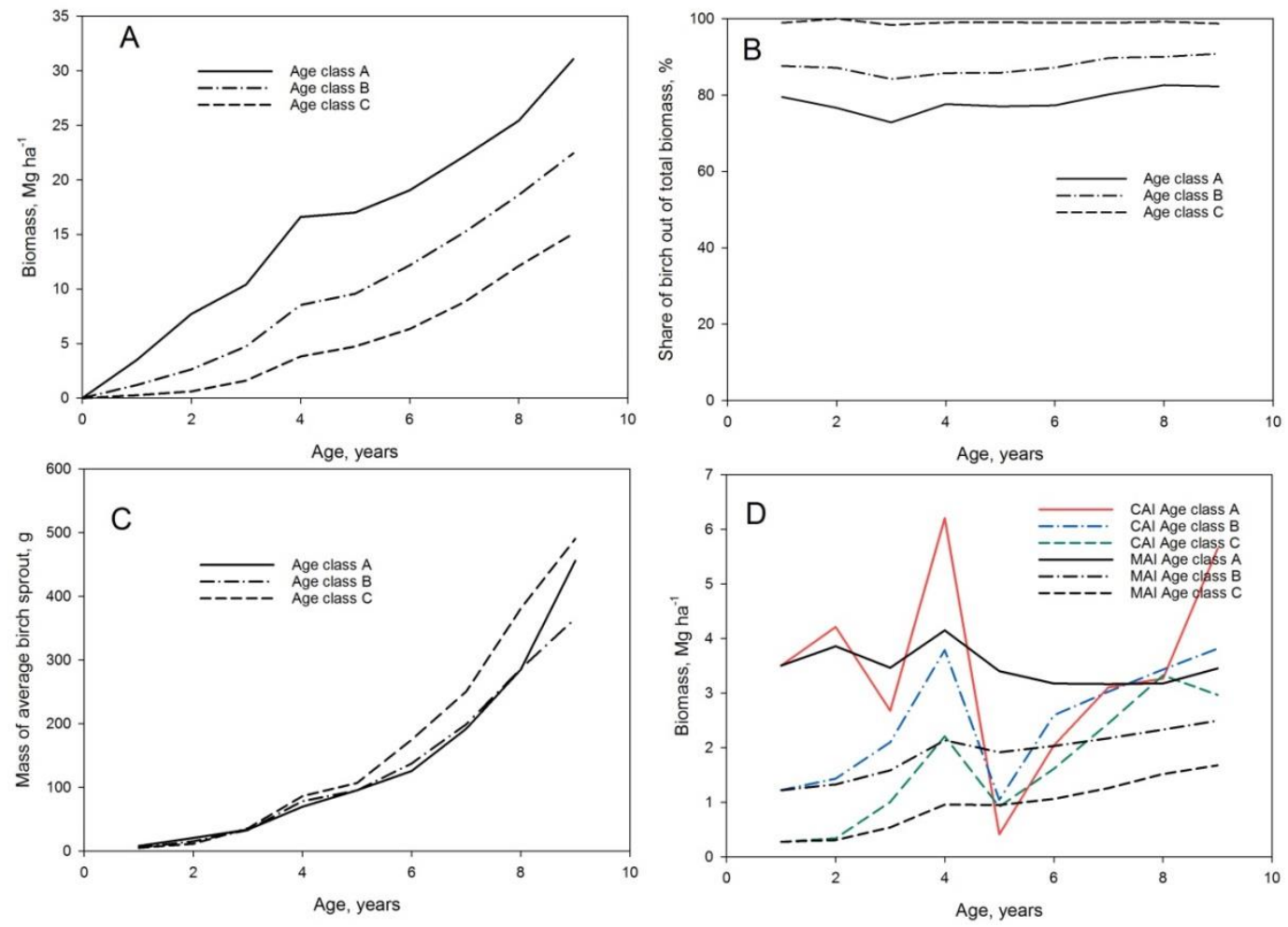

Figure 5. Biomass of sprouts (A), share of birch out of total biomass (B), biomass of average birch sprout (C), and MAI and CAI of birch and willow in the age classes (D).

\subsection{Damage}

The share of moose browsed sprouts did not differ significantly by age classes or study years. The worst damage took place already in the first year when $19 \%$ of the sprouts in age class B had been 
browsed (Figure 6). Later, at age 6, damage to the same stands was 7\%. Other major damage occurred in winter 2014-2015, when heavy snowfall bent the birch stems to the ground. However, the birch stems did not break and the number of bent stems was not measured.

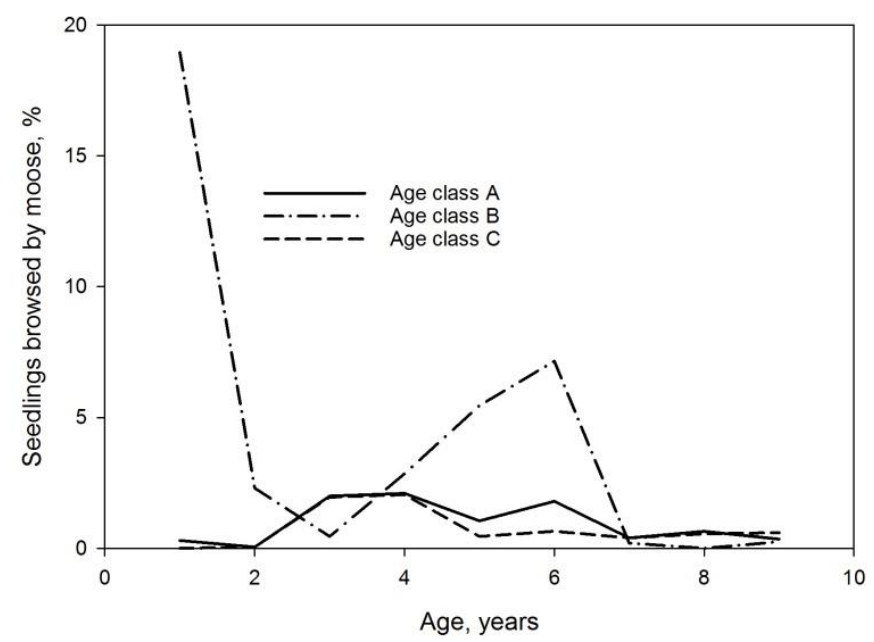

Figure 6. Amount of sprouts damaged by moose.

\section{Discussion}

Several factors, such as stump height, stump diameter, and age of trees, affecting the sprouting of downy birch are well known [20]. The sprouting of downy birch has been studied with the aim mostly at finding means to control birch sprouting since fast-growing sprouts often impair the development of softwood forest plantations. However, the development of coppiced birch stands has been studied much less. In this study, birch stands were cut at the beginning of May when the trees were still leafless and the growing season had not yet begun. Results after the first growing season showed that an increase in the diameter of stumps led to higher numbers of sprouts produced per stump, and a higher mean, dominant and cumulative height of sprouts per stump with a higher biomass of sprouts per stump [20]. In addition, the oldest stands (22-24 years old) had the highest numbers of non-sprouting stumps, which may decrease their suitability for the coppice system [20]. In this study, the number of sprouts, their height, and the biomass development of the coppices was followed for nine years.

After clearcutting the number of sprouts in the study stands were very high, especially in the youngest stand age class (A) in which the number of stumps was highest. In the youngest stand age class, especially during the first few years after clearcutting, the self-thinning was also strong, halving the original stem number in four years, whereas in the oldest age class $(C)$, the stem number almost halved after nine years. Thus the stand density approached each other in the different age classes with the increase of time. Self-thinning in the stands is expected to continue with a reduced rate and the stem number will decrease. In earlier studies in coppiced birch stands, dense planted stands and naturally regenerated stands on cutaway peatlands, the stem number has reached 9000-11,000 stems ha ${ }^{-1}$ after 20-25 years [21-23].

The age class of the original stands did not affect the mean or dominant height of the sprouts originating from the stumps. The dominant height development of the birch sprouts in this study was up to eight years faster than in the study by Hytönen and Issakainen [24], but the mean height development was slower than in the study by Hytönen and Aro [22].

The height development of the sprout-originated birches was faster than that of the seed-originated seedlings. Already after the first growing seasons, the sprout-originated birches were, on average, $116 \mathrm{~cm}$ tall while the height of 10-20 cm had been reported for one-year-old seed-originated seedlings [5,25]. Kauppi et al. [26] compared the height development of both seed-originated and sprout-originated downy birches. Sprouts developed much more rapidly than seedlings during the first three seasons, 
as a consequence of the free growth pattern and associated pronounced growth flushes. Their annual height increment declined somewhat after a few years, however, whereas that of trees of seed origin remained constant or increased slightly. On the same cutaway peatland area, Huotari et al. [5] studied the development of seeded and naturally regenerated birches for four years. The dominant height of sprout-originated seedlings in this study was $12,9,6$, and 5 times higher than that in the best fertilization treatment (mixed ash) of their study after the first, second, third and fourth growing seasons, respectively. The dominant height of four-year-old sprout originated birches in this study was much higher than that of seed originated birches $(3.1 \mathrm{~m}$ vs. $0.7 \mathrm{~m})$ in the study of Huotari et al. [5]. The dominant height of sprout-originated birches reached $5.5 \mathrm{~m}$ after nine growing seasons. However, there is very little knowledge on the long term development of sprout-originated birches. It is believed that sprout-originated seedlings will lose their growth advantage after some years. However, there are indications that seedling-originated birch stands outstrip sprout-originated seedlings in height after 20-40 years [10,27].

The biomass development depended on the age of the original clearcut downy birch stand. The younger the original stand, the faster the biomass increased. The older the stands age class was, the fewer stems there were due to self-thinning. The main factor in the first years after clearcutting explaining the differences between the age classes was the number of stumps in the stands. However, the effect of the number of stumps decreased with age, and this was no longer significant after six growing seasons. There are only a few studies on the biomass production of dense sprout-originated downy birch stands. In the study by Hytönen and Aro [22], leafless above-ground biomass was 20-25 Mg ha ${ }^{-1}$ eight years after the clearcutting of ash or PK-fertilized 16-year-old birch stands on cutaway peatlands. In the same age class (B, 15-16 years), the corresponding biomass was $19 \mathrm{Mg} \mathrm{ha}^{-1}$ and in the youngest stand age class (A, 10-12 years) similar $\left(25 \mathrm{Mg} \mathrm{ha}^{-1}\right)$ in this study.

The MAI of the coppices depended on the age class of the stands, being highest throughout the study period in the youngest age class (A). Studies on the development of coppiced birch stands are rare. Hytönen and Aro [22] studied the development of birch coppices following the clearcutting of 16-year-old naturally regenerated birch stands. In their study, the MAI of fertilized (PK or wood ash) coppices at the age of 8 years $\left(2.5-3.1 \mathrm{Mg} \mathrm{ha}^{-1} \mathrm{a}^{-1}\right)$ was similar than in this study in stand age classes $\mathrm{A}$ and B. However, in the unfertilized coppices, the MAI was $1.4 \mathrm{Mg} \mathrm{ha}^{-1} \mathrm{a}^{-1}$ [22], is lower than in the age class $\mathrm{C}$ of this study. After eight growing seasons following the coppicing of 20-year-old downy birch stands, Hytönen and Issakainen [24] found similar MAI in central Finland than stand age classes $\mathrm{A}$ and B in this study. In northern Finland, the MAI was similar than in stand age class C.

Compared to the very dense (250,000 seedlings per ha) seed-originated birch stands of Huotari et al. [5], the woody biomass in this study was manifold after four growing seasons despite the fact that the study by Huotari et al. [5] included foliage, which in young plants may constitute a high proportion of the biomass. The MAI of the naturally regenerated stands of this study before clearcutting was in stand age class A (10-12 years) $2.6 \mathrm{Mg} \mathrm{ha}^{-1} \mathrm{a}^{-1}$, and considerably higher $\left(3.5 \mathrm{Mg} \mathrm{ha}^{-1} \mathrm{a}^{-1}\right)$ in the coppiced stands after nine growing seasons. Thus, after nine years, the total biomass in the coppiced stands was higher than in the same stands before clearcutting at the age of 10-12 years. Therefore, to reach the same biomass production coppiced stands, 2-3 years shorter rotation was needed than in the seed-originated clearcut mother stands. This verified the assumption that coppice stands develop faster than seed-originated stands when the age of clearcut trees is 10-12 years. In the older stand age classes, the MAI before clearcutting was 3.0-3.1 $\mathrm{Mg} \mathrm{ha}^{-1} \mathrm{a}^{-1}$ and $1.7-2.5 \mathrm{Mg} \mathrm{ha}^{-1} \mathrm{a}^{-1}$ following clearcutting after nine years. Hence, in the older clearcut stands, a longer rotation is needed to reach a similar MAI than in the naturally regenerated stands.

The above-ground MAI in the seed-originated downy birch stands studied by Hytönen et al. [27] increased with the age of trees up to 15 years, when it reached $3.2 \mathrm{Mg} \mathrm{ha}^{-1} \mathrm{a}^{-1}$. A similar MAI was reached in the youngest age class of coppiced stands of this study already in the first growing season and was still similar after nine growing seasons. Similar or slightly higher values have been reported in dense unthinned seed-originated downy birch stands in Finland (2.5-5.7 $\mathrm{Mg} \mathrm{ha}^{-1} \mathrm{a}^{-1}$; [12,22,28-30]), 
in Ireland (from 3.1 to $5.8 \mathrm{Mg} \mathrm{ha}^{-1} \mathrm{a}^{-1}$, [31]), and in Sweden (0.5-4.4 $\mathrm{Mg} \mathrm{ha}^{-1} \mathrm{a}^{-1}$, [32]). However, the MAI in the older clearcut stands with fewer stumps per ha was smaller in the age class B $2.5 \mathrm{Mg} \mathrm{ha}^{-1}$.

The CAI of all of the stands exceeded the MAI at the age of nine years. Thus the optimum rotation period of coppiced birch stands is much longer than nine years. During winter 2014-2015, heavy snowfall and wet snow caused damage to trees in Central and northern Finland [33,34]. In the study areas, snow bent birch sprouts close to the ground but did not break them. Especially strong damage was noted in the youngest age class. The bending of birch trees in 2015 was widely reported (e.g., [35]), which caused a marked decline in growth in the following year, seen as much lower CAI. Birches are susceptible to bending, and birch-dominated forests are, in most cases, less severely damaged than coniferous forests [36-38]. Moose can also damage birch sprouts, but the damage remained quite small during the nine study years. The highest damage was measured in the age class $B$ in the first summer, where moose had mostly eaten leaves from the birches. Probably, the selection of these stands was based on their location farther away from forest roads.

The dry weight of sprouts on a stump has shown to increase with increases in stump diameter from 1 to at least $9 \mathrm{~cm}$, and fast-growing young stands producing stumps sized $9 \mathrm{~cm}$ have been considered to be ideal for short-rotation management of birch $[20,39]$ The total biomass of the sprouts on an area basis in the study stands was related to the number of trees in the stands. Those young stands having more stumps per hectare than the older stands had a higher biomass on an area basis. However, due to self-thinning, the stem numbers in younger, clearcut dense stands decreases faster than in the older clearcut stands and the difference in stem numbers is smaller. As well as this, in the older clearcut stands with fewer stumps per hectare, the weight of one sprout was higher than in the denser stands. The stump number correlated in the beginning with the biomass production but not at the end of the study period. Thus with the increase of age, it is expected that growth in the older stand age classes will increase, and their biomass will also reach that of the seed-originated clearcut stands so that coppice rotation will be shorter.

\section{Conclusions}

The younger the clearcut stand is, the higher the initial number of spouts was. However, due to self-thinning, sprout densities approached each other in the different age classes with the increase of time. Since the age of trees before clearcutting did not affect the height development of sprouts biomass is mainly a function of the number of sprouts. The study by Jylhä et al. [7] demonstrated the economic feasibility of energy biomass production in dense naturally regenerated downy birch stands with rotations over 23 years. They assumed that after the clearcutting, subsequent tree generations were assumed to be established by coppicing. This study verifies that at least one coppice rotation is possible. Additionally, the assumption that, due to coppicing vigor, the coppice rotation was expected to be one year shorter than the first seed-originated rotation was verified in the youngest age class. However, it is likely that this is true also in the older age classes since coppice vigor increases the growth of sprouts, and sprout-originated downy birches grow more quickly than seed-originated trees for 15-20 years [25]. Thus, the coppice management of birches aged 25-30 years may be possible.

Funding: This research received no external funding.

Acknowledgments: Jorma Issakainen, Heikki Vesala, and Kauko Kylmänen are acknowledged for establishing the experiments, and Seppo Vihanta and Eero Saari for measuring them. In addition, Seppo Vihanta helped with data handling. Olli Reinikainen is acknowledged for inspiring discussions.

Conflicts of Interest: The author declares no conflict of interest. 


\section{References}

1. Dimitriou, I.; Mola-Yudego, B. Poplar and willow plantations on agricultural land in Sweden: Area, yield, groundwater quality and soil organic carbon. For. Ecol. Manag. 2016, 383, 99-107. [CrossRef]

2. Mola-Yudego, B.; Rahlf, J.; Astrup, R.; Dimitriou, I. Spatial yield estimates of fast-growing willow plantations for energy based on climatic variables in Northern Europe. GCB Bioenergy 2016, 8, 1093-1105. [CrossRef]

3. Hytönen, J. Biomass production and nutrition of short-rotation plantations. Metsäntutkimuslaitoksen Tiedonantoja 1996, 586, 1-61.

4. Korhonen, K.T.; Ihalainen, A.; Heikkinen, J.; Henttonen, H.; Pitkänen, J. Forest resources by forestry centre in Finland in 2004-2006 and the development of forest resources in 1996-2006. Metsätieteen Aikakauskirja 2007, 2B, 1-213. [CrossRef]

5. Huotari, N.; Tillman-Sutela, E.; Pasanen, J.; Kubin, E. Ash-fertilization improves germination and early establishment of birch (Betula pubescens Ehrh.) seedlings on a cut-away peatland. For. Ecol. Manag. 2008, 255, 2870-2875. [CrossRef]

6. Hytönen, J.; Ahtikoski, A.; Aro, L.; Jylhä, P. Short-rotation downy birch for energy on cutaway peatlands: Cultivation, harvesting and financial performance. Suo-Mires Peat 2016, 67, 13-17.

7. Jylhä, P.; Hytönen, J.; Ahtikoski, A. Profitability of short-rotation biomass production on downy birch stands on cut-away peatlands in northern Finland. Biomass Bioenergy 2015, 75, 272-281. [CrossRef]

8. Ferm, A.; Kauppi, A. Coppicing as means for increasing hardwood biomass production. Biomass 1990, 22, 107-121. [CrossRef]

9. Kauppi, A.; Rinne, P.; Ferm, A. Initiation, structure and sprouting of dormant basal buds in Betula pubescens. Flora 1987, 179, 55-83. [CrossRef]

10. Kauppi, A.; Rinne, P.; Ferm, A. Sprouting ability and significance for coppicing of dormant buds on Betula pubescens Ehrh. stumps. Scand. J. For. Res. 1988, 3, 343-354. [CrossRef]

11. Johansson, T. Dormant buds on Betula pubescens and Betula pendula stumps under different field conditions. For. Ecol. Manag. 1992, 47, 245-259. [CrossRef]

12. Ferm, A. Coppicing, aboveground woody biomass production and nutritional aspects of birch with specific reference to Betula pubescens. Finnish For. Res. Inst. 1990, 348, 1-35.

13. Etholén, $\mathrm{K}$. The effect of felling time on the sprouting of Betula pubescens and Populus tremula in the seedling stands in the northern Finland. Folia For. 1974, 213, 16.

14. Jobidon, R. Stump height effects on sprouting of mountain maple, paper birch and pin cherry-10 year results. For. Chron. 1997, 73, 590-595. [CrossRef]

15. Johansson, T. Sprouting of 2-to 5-year-old birches (Betula pubescens Ehrh. and Betula pendula Roth) in relation to stump height and felling time. For. Ecol. Manag. 1992, 53, 263-281. [CrossRef]

16. Johansson, T. Sprouting of 10-to 50-year-old Betula pubescens in relation to felling time. For. Ecol. Manag. 1992, 53, 283-296. [CrossRef]

17. Johansson, T. Sprouting ability and biomass production of downy and silver birch stumps of different diameters. Biomass Bioenergy 2008, 32, 944-951. [CrossRef]

18. Hytönen, J. Effect of cutting season, stump height and harvest damage on coppi $\neg$ cing and biomass production of willow and birch. Biomass Bioenergy 1994, 6, 349-357. [CrossRef]

19. Kang, H. The prevention and handling of the missing data. Korean J. Anesthesiol. 2019, 64, 402-406. [CrossRef]

20. Hytönen, J. Stump diameter and age affect coppicing of downy birch (Betula pubescens Ehrh.). Eur. J. For. Res. 2019, 138, 345-352. [CrossRef]

21. Hytönen, J.; Saarsalmi, A. Long-term biomass production and nutrient uptake of birch, alder and willow plantations on cut-away peatland. Biomass Bioenergy 2009, 33, 1197-1211. [CrossRef]

22. Hytönen, J.; Aro, L. Biomass and nutrition of naturally regenerated and coppiced birch on cutaway peatland during 37 years. Silva Fenn. 2012, 46, 377-394. [CrossRef]

23. Hytönen, J.; Issakainen, J. Effect of repeated harvesting on biomass production and sprouting of Betula pubescens. Biomass Bioenergy 2001, 20, 237-245. [CrossRef]

24. Kaunisto, S. Rauduskoivun (Betula pendula) ja hieskoivun (Betula pubescens) luontainen uudistuminen turpeennoston jälkeisellä suonpohjan turpeella Kihniön Aitonevalla. Summary: Natural regeneration of Betula pendula and B. pubescens on a peat cut-away area. Suo 1981, 32, 53-60. 
25. Kauppi, A.; Kiviniitty, M.; Ferm, A. Growth habits and crown architecture of seed and sprout origin Betula pubescens Ehrh. Can. J. For. Res. 1988, 18, 1603-1613. [CrossRef]

26. Mikola, P. On sprouting of birch and its silvicultural significance. Acta For. Fenn. 1942, 50, 102, In Finnish with German summary. [CrossRef]

27. Hytönen, J.; Aro, L.; Jylhä, P. Biomass production and carbon sequestration of dense downy birch stands on cutaway peatlands. Scand. J. For. Res. 2018, 33, 764-771. [CrossRef]

28. Björklund, T.; Ferm, A. Pienikokoisen Koivun Ja Harmaalepän Biomassa Ja Tekniset Ominaisuudet. Abstract: Biomass and Technical Properties of Small-Sized Birch and Grey Alder. Folia For. 1982, 500, 1-37.

29. Hytönen, J.; Kaunisto, S. Effects of fertilization on the biomass production of coppiced mixed birch and willow stands on a cut-away peatland. Biomass Bioenergy 1999, 17, 455-469. [CrossRef]

30. Niemistö, P. Effect of growing density on biomass and stem volume growth of downy birch stands on peatland in western and northern Finland. Silva Fenn. 2013, 47. [CrossRef]

31. Renou-Wilson, F.; Pöllänen, M.; Byrne, K.; Wilson, D.; Farrell, E.P. The potential of birch afforestation as an after-use option for industrial cutaway peatlands. Suo 2010, 61, 59-76.

32. Johansson, T. Biomass equations for determining fractions of pendula and pubescent birches growing on abandoned farmland and some practical implications. Biomass Bioenergy 1999, 16, 223-238. [CrossRef]

33. Jalkanen, R. Lapin Metsätuhot 2015. In Metsätuhot Vuonna. Available online: https://jukuri.luke.fi/handle/ 10024/535832 (accessed on 25 August 2020).

34. Lehtonen, I. Vaikea Tykkylumitilanne Jatkuu Kainuussa. 2018. Available online: www.ilmatieteenlaitos.fi/ ajankohtaista/464823858 (accessed on 25 August 2020).

35. Vesterinen, A. Tykky se taivutti koivun latvan. Metsänomistajat Pohjois-Savo 2015, 2/2015, 21.

36. Nykänen, M.-L.; Peltola, H.; Quine, C.P.; Kellomäki, S.; Broadgate, M. Factors affecting snow damage of trees with particular reference to European conditions. Silva Fenn. 1997, 31, 193-213. [CrossRef]

37. Päätalo, M.-L. Risk of snow damage in unmanaged and managed stands of Scots pine, Norway spruce and birch. Scand. J. For. Res. 2000, 15, 530-541. [CrossRef]

38. Martiník, A.; Mauer, O. Snow damage to birch stands in Northern Moravia. J. For. Sci. 2012, 58, $181-192$. [CrossRef]

39. Johansson, T. Development of stump suckers by Betula pubescens at different light intensities. Scand. J. For. Res. 1987, 2, 77-83. [CrossRef] 